\title{
Brexit, COVID-19 and Attitudes Towards Immigration in Britain
}

\author{
Mark Pickup \\ (Associate Professor, Simon Fraser University) \\ mark.pickup@sfu.ca \\ Eline de Rooij \\ (Associate Professor, Simon Fraser University) \\ eline_de_rooij@sfu.ca \\ Clifton van der Linden \\ (Assistant Professor, McMaster University) \\ cliff.vanderlinden@mcmaster.ca \\ Matthew Goodwin \\ (Professor, University of Kent) \\ M.J.Goodwin@kent.ac.uk
}

\begin{abstract}
A key issue in Britain's referendum on European Union membership was the free movement of labour into Britain, with Brexit 'Leavers' having more negative attitudes towards immigrants compared to 'Remainers'. Such anti-immigrant attitudes are driven by feelings of threat. As Brexit negotiations continued, the coronavirus pandemic presented a new threat, potentially heightening anti-immigrant attitudes. However, the prominent sacrifices of migrant workers in the fight against coronavirus suggests a potential for softening public attitudes. We ask: how did the COVID-19 pandemic, in the context of ongoing Brexit negotiations, affected antiimmigrant attitudes and how did these effects differ between Leavers and Remainers? Through a survey experiment, we test the effects of priming COVID-19 thoughts, showing that COVID-19 may exacerbate anti-immigrant attitudes among Leavers while having little effect on Remainers. In doing so, we explore the effect of a viral threat on immigration attitudes and heterogeneity in that effect, based on political identities.
\end{abstract}


The outcome of the United Kingdom's 2016 referendum on membership of the European Union (EU) was influenced by strong and highly salient public attitudes toward immigration. As a now large literature on the Brexit vote makes clear, public opposition to immigration into Britain from EU member states, and/or negative attitudes about the perceived effects of immigration on the country, were among the strongest drivers of public support for 'Leave' (for reviews of this evidence see Eatwell and Goodwin, 2018; Kaufmann 2018). Such anti-immigrant attitudes are driven by perceived threats. On the other hand, research since the referendum has pointed to the decreased salience of immigration and a 'softening' of public attitudes toward immigrants and immigration (Ford 2018; Schwartz et al. 2020).

In this paper, we ask how the new threat of the recent coronavirus pandemic might affect anti-immigrant attitudes, in the context of the Brexit negotiations, ongoing at the time of the pandemic's start. Coming against the backdrop of Brexit and a protracted national debate about immigration, could the outbreak of COVID-19 heighten anti-immigrant attitudes? Conversely, given that migrant workers have been a prominent story of the pandemic - with many overseas nurses and doctors dying during the crisis-could this further encourage a softening of public attitudes as noted by the studies listed above? Finally, how do these potential effects differ by those that identify as Brexit 'Remainers' and 'Leavers'? In answering these questions, we explore the effect of a viral threat on immigration attitudes and heterogeneity in that effect, on the basis of political identities. Below we review the current understanding of the role of perceived threats from immigrants on anti-immigrant/immigration attitudes and support for Brexit. We then outline our expectations regarding the effect of the coronavirus pandemic on anti-immigrant/immigration attitudes amongst Remainers and 
Leavers. We then describe the design of and the results from a survey experiment conducted to test those expectations.

In recent years there has emerged a vast literature on the drivers of anti-immigrant and anti-immigration sentiment (see for overviews Ceobanu and Eskandell 2010; Hainmuller and Hopkins 2014). A central element in many explanations is the role of perceived threats, especially 'realistic' threats and 'symbolic' threats, both to the social identity group (ethnic, class, etc.) an individual belongs to and to the individual themselves (Stephan et al. 2009). ${ }^{1}$

Symbolic threats include threats to one's national culture, values and "way of life" and emphasize the role of social identity groups and/or symbolic concerns. Realistic threats result from conflict over scarce resources (e.g. jobs, government benefits, housing) and valued goods - political and economic power, but also the group's well-being more broadly (Stephan et al. 2009). They can concern the material self-interest of individuals, or the group as a whole. Realistic threats can also include the perceived threat of disease and contamination (Faulkner et al 2004; Navarrete and Fessler 2006). Recent research suggests that immigrants can trigger the behavioral immune system (Aarøe et al. 2017) - psychological mechanisms that "detect cues connoting the presence [threat] of infectious pathogens in the immediate environment" (Schaller and Park 2011).

\footnotetext{
${ }^{1}$ Older versions of intergroup threat theory also included threats resulting from intergroup anxiety and negative stereotypes (Stephan et al. 2005: 3).
} 
In general, threats to the group (sociotropic threats) have been found to be strong predictors of anti-immigrant/immigration sentiment (Hainmuller and Hopkins 2014; Sniderman, Hagendoorn and Prior 2004; Quillian 1995). In contexts in which such sociotropic threats increase, negative sentiment is said to increase. Accordingly, research shows that (sub-)national economic conditions (e.g., employment rates, affluence, recessions), differences in the size of immigrant groups and sudden increases in the flow of immigrants (Ceobanu and Eskandell 2010; Hainmuller and Hopkins 2014) impact anti-immigrant and anti-immigration attitudes. Although these conditions have not necessarily translated into increased support for radical right parties (Amengay and Stockemer 2019), scholars have argued that in Britain these conditions played a role in increased support for Brexit.

Anti-immigration attitudes and threat perceptions have consistently been found to have been stronger predictors of support for Leave than economic factors, such as income or employment status. For example, Goodwin and Milazzo (2017) find that citizens who felt the most strongly negative about immigration and its effects were more likely to vote Leave. Hobolt (2016) found that support for Brexit was not only concentrated among less well educated and older voters but among those who 'expressed concerns about immigration and multiculturalism'. Curtice (2017) found that this vote was driven strongly by a sense that EU membership was damaging Britain's 'distinctive sense of identity', of which the perceived threat from immigration was central. Clarke et al. (2017) similarly found that negative attitudes toward immigration influenced broader perceptions of risk: individuals who felt negatively about immigration were not only more likely to vote Leave but when making their decisions were also less likely to perceive Brexit as a risk. 
British Election Study (BES) researchers have argued that large-scale immigration became one of several significant external 'shocks' for British voters, alongside others such as the post-2008 global financial crisis. The shock of large-scale immigration not only increased the salience of this issue but also heightened electoral volatility and provided a market for antiimmigration challenger parties such as the populist UK Independence Party and then, in 2019, its successor, the Brexit Party (Fieldhouse et al. 2020). After controlling for the effect of overall migration and other variables, Goodwin and Heath (2016; see also Colantone and Stanig 2018) find that local districts that experienced a rapid increase in levels of EU migration over the preceding decade were more likely to endorse Brexit.

Interestingly, post-Brexit anti-immigrant (Schwartz et al. 2020) and anti-immigration sentiment (Ford 2018) have softened again among both Leavers and Remainers. Schwartz et al. attribute this softening to a greater sense of control over immigrant flows among Leavers and a distancing from accusations of xenophobia and racism among both Leavers and Remainers (2020). ${ }^{2}$ However, the sudden outbreak of COVID-19 signalled the arrival of yet another big external 'shock', potentially leading citizens once again to feel under threat. Feelings of threat from the pandemic may, for example, take the form of realistic threats regarding access to healthcare and government support, symbolic threats to one's (pre-COVID) way of life, or might result from negative stereotypes suggesting individuals with a particular heritage are responsible for spreading the virus. Research on past infectious diseases show that individuals often attribute the spread of the disease to the characteristics and actions of out-groups (Eicher

${ }^{2}$ See Harell, Soroka, and lyengar (2017) for a discussion of the role of perceptions of control. 
and Bangerter 2015) as a way of controlling anxiety with respect to the disease (Joffe 1999). In the case of COVID-19, that could be the characteristics and actions of those of Chinese and/or Asian heritage, where the disease is thought to have originated, or of Italian or Spanish heritage, where the disease (at the time) was viewed as spreading faster than other parts of Europe. ${ }^{3}$ These feelings of threat have the potential to inflame anti-immigrant attitudes. ${ }^{4}$ Even prior to the pandemic, research suggests that those with high disgust sensitivity viewed immigrants as a potential pathogen threat, motivating anti-immigration sentiments (Aarøe et al. 2017). Importantly, the resulting anti-immigrant attitudes need not be restricted to particular out-groups (e.g. Chinese or Spanish) but can be directed at low status out-groups in general (Cadinu and Reggiori 2002). For instance, sudden threatening events such as terrorist attacks (Das et al. 2009) or an outbreak of large-scale rioting (de Rooij, Goodwin and Pickup 2015) have been shown to heighten prejudice towards outgroups generally, regardless of whether outgroup members were identified as perpetrators in the attack or as participants in the riots. ${ }^{5}$ It is also possible that the increased fear of death that the pandemic may have

\footnotetext{
${ }^{3}$ Arguably, it spread just as fast in the UK.

${ }^{4}$ There were stories in the media of coronavirus-related hate crimes in the UK and abroad.

${ }^{5}$ De Rooij, Goodwin and Pickup (2015), for instance, show how an outbreak of rioting in the UK increased concerns about threats to British culture and about increased violence and vandalism in British society, and how this impacted hostility towards both Black British and East European minorities, and Das et al. (2009) use Terror Management Theory (TMT) to explain how (news of) a terrorist attack increases thoughts of death, which in turn leads to prejudice against outgroups.
} 
created has made individuals more sensitive to threats, both symbolic and realistic (Stephan et al 2009). In other words, those that already felt that immigrants represent a threat to their resources, culture and way of life may be even more sensitive to these feelings during the pandemic.

A key role in whether events are perceived as threatening and result in negative attitudes towards minority groups, is played by elites, the media and framing (Valentino, Brader, and Jardina 2013; Brader, Valentino and Suhay 2008; Eicher and Bangerter 2015; Hainmuller and Hopkins 2014, 233-4; Osborn, Sosa and Rios 2020). Although COVID as a threat was widely communicated through the media, there were also stories in the media about migrant nurses and doctors fighting on the front lines against coronavirus and in some cases dying. Such stories have the potential to decrease anti-immigrant attitudes. In March 2020, it was widely reported that migrant doctors, nurses and paramedics would have their visas extended so that they could 'focus on fighting coronavirus'. The next week, it was reported that eight migrant doctors had died in the UK as a result of tackling coronavirus and in early April 2020 Prime Minister Boris Johnson publicly thanked the migrant nurses and doctors for saving

TMT has not been much used in political science but is well-known in psychology. It posits that thoughts of death trigger a defense of our "internalized cultural worldview" and of that part of our self-esteem that is derived from belonging to a particular identity group --both key in providing a sense of psychological security-- and which in turn leads to "negative reactions to others who subscribe to different worldviews" and/or who threaten this "group-identificationbased self-esteem" (Greenberg et al. 2016: 110-2). 
his life. In the same month it was revealed that while people from black, Asian or other minority ethnic backgrounds comprise 44 per cent of all healthcare workers in the National Health Service, 72 percent of healthcare workers who had died while helping patients on the front lines came from these backgrounds. In sum, one of the dominant media narratives of the outbreak in Britain focused on the sacrifice of doctors and nurses from minority ethnic backgrounds. Research suggests that exposure to counter-stereotypical examples in news stories of members of racial and/or ethnic minority groups can increase favorable attitudes towards the minority group and policies that affect the group (e.g., Ramasubramanian 2015).

The impact of threat perceptions on anti-immigrant attitudes is not expected to be uniform. Certain types of individuals are more likely to perceive threats and to display antiimmigrant sentiment (Ceobanu and Eskandell 2010). The effects of threat on immigration attitudes are expected to be heterogeneous across a population. The leave campaign during Brexit played on and reinforced Leavers' feelings that immigrants threatened to take jobs from native Britons and were a threat to the 'British way of life'. In the context of Brexit negotiations, it would presumably not be difficult for the spread of an infectious disease to further prime feelings of threat. This might be by exacerbating pre-existing perceptions of immigrants as a pathogen threat or by making individuals more sensitive to outgroup threats generally (symbolic and realistic). Further, regarding the positive coverage of immigrants in the news media, we would expect motivated reasoning to lessen any impact this might have on Leavers' attitudes. Motivated reasoning with respect to partisan identities is well established (inter alia Anderson et al. 2004, Evans and Andersen 2006; Evans and Pickup 2010) and Hobolt and Sorace 
(2020) demonstrate motivated reasoning linked to Brexit identities. ${ }^{6}$ Theories of motivated reasoning (Taber and Lodge 2006) suggests Leavers will be predisposed to filter out positive messages about immigrants' role in fighting coronavirus, given these messages are inconsistent with prior Brexit beliefs (Hobolt, Leeper and Tilley 2020). It is more likely that the coronavirus will increase the perception of immigrants as a threat among Leavers. This is far less likely among Remainers who were unaffected by the 'immigrants as threat' messaging during Brexit. Meanwhile, positive messages regarding the role of immigrants in the fight against coronavirus are consistent with the prior beliefs of Remainers and so have the potential to produce more positive immigration attitudes among this group. Further, research has shown that threat can actually increase positive behaviours towards outgroup members amongst those that wish to appear unprejudiced (Stephan et al 2007).

We hypothesize that the negative effects of COVID-19 on immigration attitudes in the context of Brexit negotiations are most likely to occur amongst Brexit Leavers and positive effects are most likely to occur amongst Remainers. Note that we are not arguing that the Brexit identity - identifying as a 'Leaver' or 'Remainer' - is a causal moderator. Rather, we are arguing that because the Brexit identity has become such a central aspect of British politics (maybe more so than partisanship; Hobolt et al. 2020) and so highly aligned with perceptions of and sensitivity to threats from immigrants, it is an effective way of capturing pre-existing attitudes, values and sociodemographic characteristics that are likely to lead to heterogeneity

\footnotetext{
${ }^{6}$ Brexit identities bias individual perceptions of the economy, and these biases are exacerbated when individuals are reminded of Brexit.
} 
in the effects of COVID-19 on immigration attitudes. ${ }^{7}$ It is not just membership in a Brexit identity group itself but the norms, values and other attributes that constitute that identity that lead to effect heterogeneity. ${ }^{8}$

\section{Research Design}

The data was collected through an online survey fielded between 14 March and 15 April 2020 $(n=3,708)$. The sample was drawn from Vox Pop Labs' online panel of approximately 35,000 individuals residing in the UK. This online panel was recruited through the 2016 Eurometer project and respondents were pre-stratified on the basis of region, age, sex and vote. Like many

${ }^{7}$ Note: the survey which included the experiment described below was designed to measure the differences between Leavers and Remainers in their preferences regarding the Brexit negotiations and this intent was preregistered. However, the questions regarding COVID-19 and the subsequent experiment were not part of that preregistration, as these questions were added at the last minute when the severity of the pandemic was just becoming apparent (and when the researcher responsible for that preregistration was busy trying to figure out how to get back to his home country).

${ }^{8}$ We could have selected other identities (e.g., social class) or attributes (e.g., education) to look for effect heterogeneity but Brexit identities were arguably the most salient political identities in Britain, given the political context at the time, and highly relevant to immigration attitudes and threat sensitivity. 
online panels, the respondents are likely more politically engaged than the average Briton. However, we are focusing on Brexit identifiers that are likely more politically engaged anyways. The survey contained 20 minutes of questions regarding the respondent's preferences regarding the ongoing Brexit negotiations. The experiment reported on in this research note followed. The experiment contained a block of questions on COVID-19 and a block of questions on attitudes towards immigration. Respondents either saw the COVID-19 block or the immigration block first. This was randomized. ${ }^{9}$ Those in the control group saw the immigration block first and those in the treatment group saw the COVID-19 block first. The COVID-19 block asked respondents: how concerned they are by COVID-19; their attitudes towards the government's current response to COVID-19; precautions they were taking in response to the potential risk posed by COVID-19; and whether they knew anyone who had contracted COVID19 (see Supplementary Information A). The immigration block asked: How many new immigrants UK should allow generally; the extent to which UK should allow migrants from poorer countries outside Europe; whether there are too many migrants from EU countries in the UK; whether migrants from EU countries were the main source of unemployment; the extent to which UK should allow migrants from poorer countries outside Europe; and whether immigrants to the UK can retain their cultural values without being less British (see Supplementary Information A).

The COVID-19 block is designed to prime respondents in the treatment group to think about COVID-19 and the risks it poses before they answered the questions in the immigration

\footnotetext{
${ }^{9}$ See Supplementary Information B for Balance test.
} 
block. ${ }^{10}$ Those in the control group were asked the immigration questions before they were asked anything about COVID-19. Of course, during the period in which a survey was fielded COVID-19 was on the minds of pretty much everyone even without the priming. Therefore, our effects are likely conservative in that they are the causal effects of additional priming. Note also that those in the control and treatment group were equally primed to think about the Brexit negotiations by the preceding 20 minute questionnaire. Therefore, we are estimating effects of COVID-19 in the context of those negotiations.

A priori, we expect the effects of COVID-19 on immigration attitudes to vary within the British population. Specifically, we look at how the effects vary by Brexit identity - whether the respondent identifies as a 'Leaver' or 'Remainer'. The question measuring this was asked before either the COVID-19 or immigration blocks.

\section{Analysis and Results}

Before looking at the results from the experiment, we report on the degree of concern felt by those in the UK as expressed in responses to the question: "How concerned are you about the threat posed to the United Kingdom by the coronavirus (COVID-19)?" on a response scale from

${ }^{10}$ The COVID-19 block also mentions the government's response which may prime partisan considerations, but these were probably already primed before the experiment in both the treatment and control groups by the nature of the Brexit survey. 
(1) "Not at all concerned" to (5) "Extremely concerned". The average response is 3.68 (SD:

1.03), which falls between between "Somewhat concerned" (3) and "Very concerned" (4).

We next turn to the experimental results to see how priming this concern in the context of Brexit negotiations translates into anti-immigrant attitudes. We look at how the responses to the immigration questions vary by whether or not the individual was first primed to think about COVID-19 and use a chi-squared statistic to determine if the differences are statistically significant.

We begin by looking at the control group for Leavers and Remainers in Figure 1. We see that descriptively Leavers are far more likely to say that the UK should admit 'somewhat less' or 'many fewer' immigrants (89.8\%) compared to Remainers (13.7\%). Without priming COVID-19, Leavers and Remainders are polarized on immigration attitudes. ${ }^{11}$ We next look at the effect of priming Leavers and Remainers to think about COVID-19 before answering questions about immigration. Among Brexit Leavers, the COVID-19 prime increases the percent of respondents indicating that the UK should admit many fewer immigrants by six percentage points (Figure 1). This is statistically significant at the 0.05 level ( $p$-value equals 0.007$).{ }^{12}$ There is a corresponding

${ }^{11}$ Figure A.1 to A.5 in the Supplementary Information C, provides a direct comparison of Leavers' and Remainers' attitudes on immigration asked about prior to treatment (those in the control group).

${ }^{12}$ All $P$-values are one-tailed. 
six percentage point drop in the percent of respondents indicating that the UK should admit somewhat less fewer immigrants. There is no discernible effect on Remainers.

Among Leavers, the COVID-19 prime increases the percent of respondents agreeing or strongly agreeing that there are too many people from EU countries living in the UK by six percentage points (Figure 2). This is statistically significant at the 0.05 level ( $p$-value equals 0.043). There is a corresponding six percentage point drop in the percent of respondents slightly agreeing or slightly disagreeing. Again, there is no discernible effect on Remainers.

We do not detect any effect of the COVID-19 prime on the extent to which respondents thought that people from poorer countries outside Europe should be allowed to come and live in the UK (Figure 3). This is true of Leavers and Remainers.

The COVID-19 prime produces a statistically significant increase of almost 6 percentage points in the percent of Leavers slightly, somewhat or strongly agreeing that migrants from other EU countries are the main cause of unemployment in the UK ( $p$-value equals 0.011 ) (Figure 4). The prime also produced a 2.6 percentage point increase in Leavers strongly disagreeing that immigrants to the UK can retain their cultural values without being any less British ( $p$-value equals 0.021). At the same time it produced a 2.2 percentage point increase in Leavers strongly agreeing with the statement. This ambiguous result is statistically significant. As before, there is no discernible effect among Remainers for either question. 
Figure 1. How many new immigrants should the UK admit?

Leave

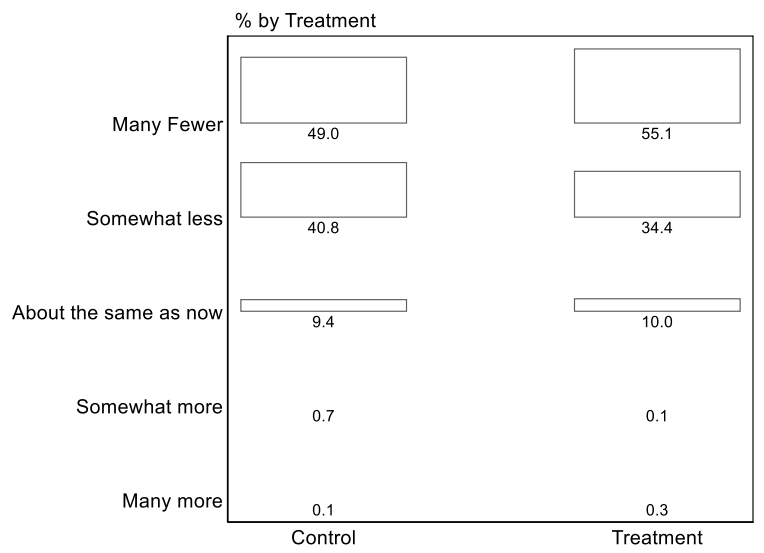

$\chi^{2}(4)=12.60 ; P$-value $($ one-sided $)=0.007 ; N=1734$
Remain

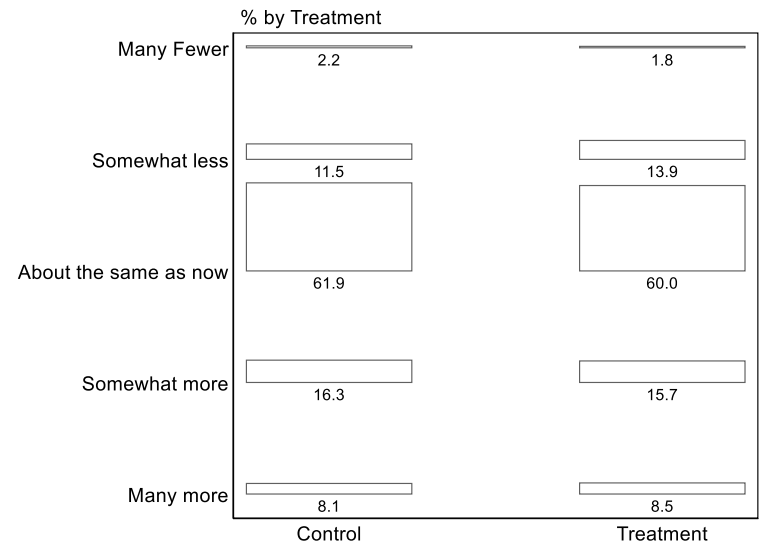

$\chi^{2}(4)=2.20 ; P$-value $($ one-sided $)=0.35 ; N=1455$

Figure 2. There are too many people from other EU countries living in the UK?

Leave

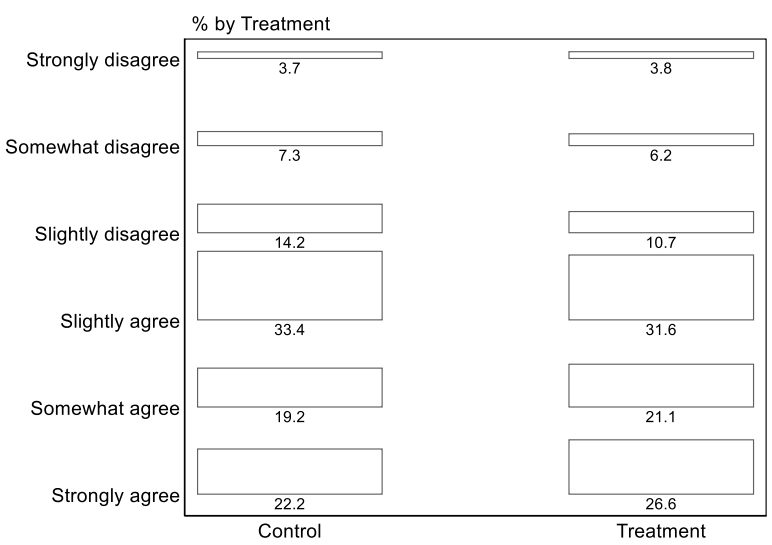

$\chi^{2}(5)=9.64 ; P$-value(one-sided) $=0.043 ; N=1734$
Remain

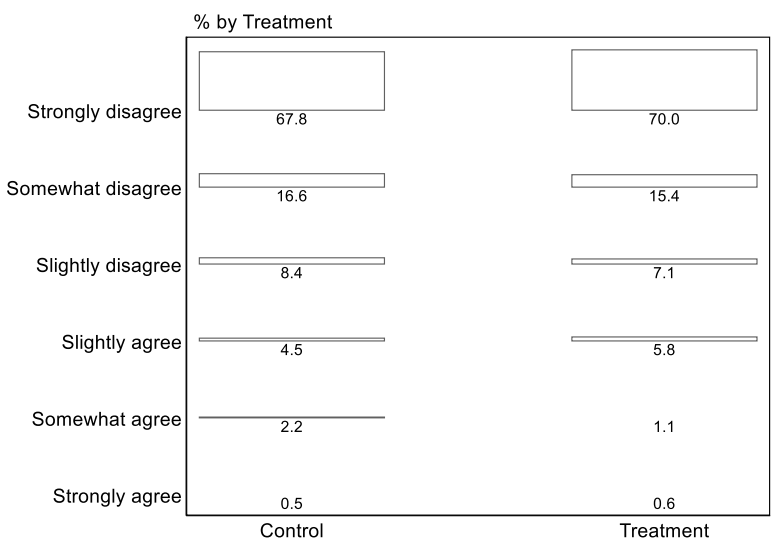

$\chi^{2}(5)=5.15 ; P$-value $($ one-sided $)=0.20 ; N=1455$ 
Figure 3. To what extent do you think the UK should allow people from the poorer countries outside Europe to come and live here?

Leave

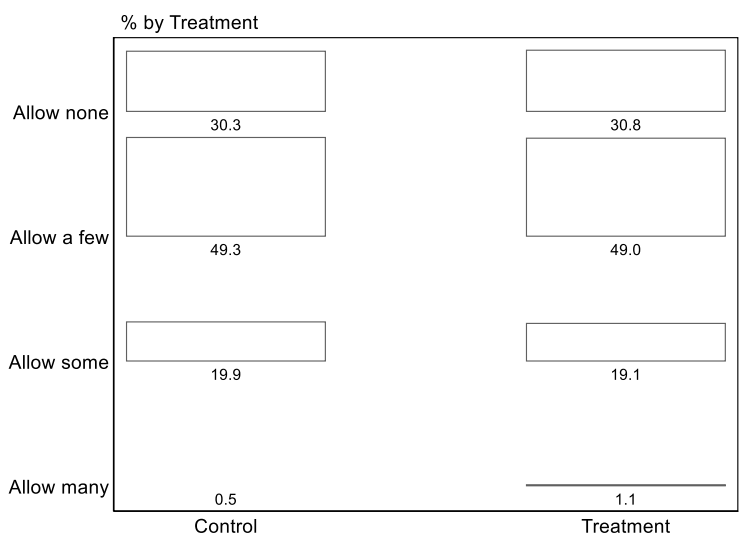

$\chi^{2}(3)=2.05 ; P$-value $($ one-sided $)=0.28 ; N=1676$

\section{Remain}

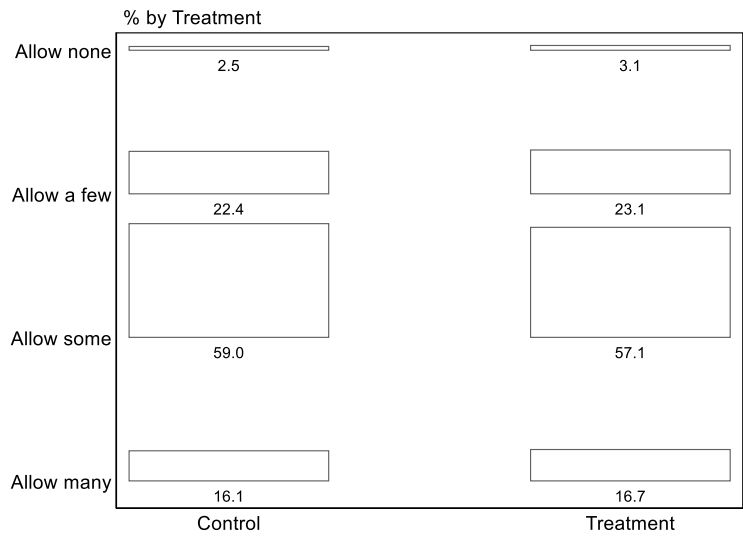

$\chi^{2}(3)=0.72 ; P$-value $($ one-sided $)=0.43 ; N=1398$

Figure 4. Migrants from other EU countries are the main cause of unemployment in the UK.

Leave

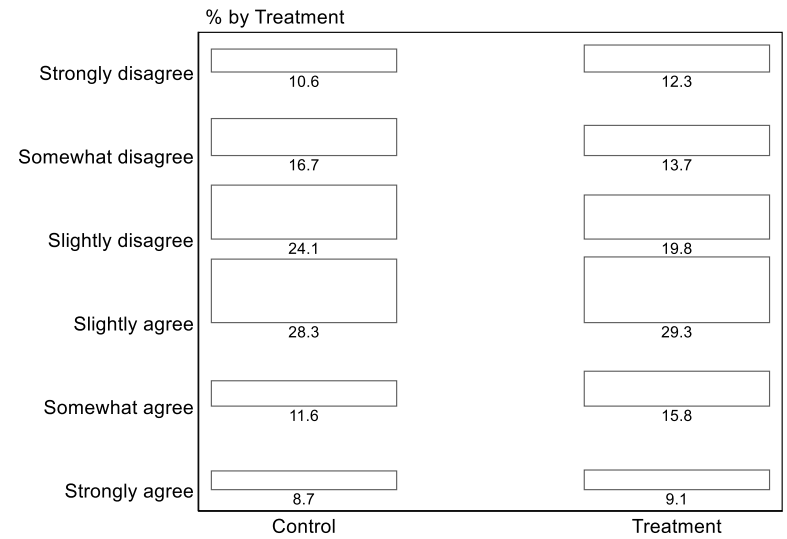

$\chi^{2}(5)=13.14 ; P$-value $($ one-sided $)=0.011 ; N=1730$
Remain

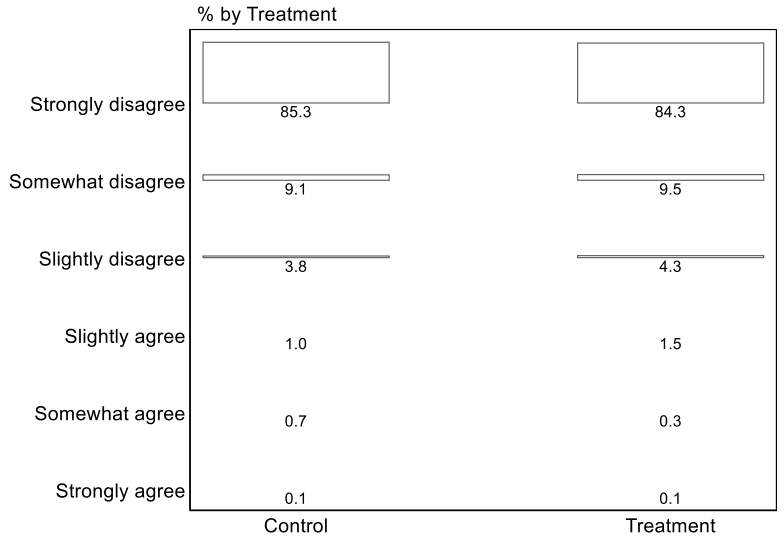

$\chi^{2}(5)=2.53 ; P$-value(one-sided) $=0.39 ; N=1453$ 
Figure 5. Immigrants to the UK can retain their cultural values without being any less British.

Leave

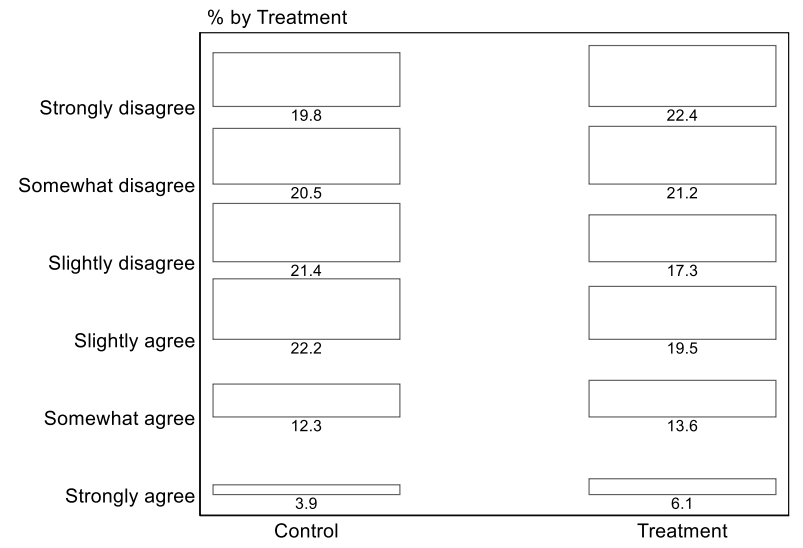

$\chi^{2}(5)=11.49 ; P$-value(one-sided $)=0.021 ; N=1733$
Remain

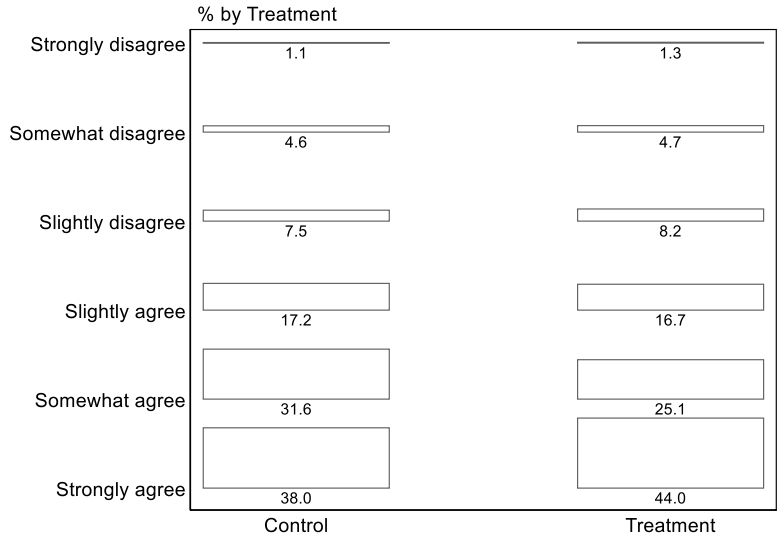

$\chi^{2}(5)=9.13 ; P$-value(one-sided) $=0.052 ; N=1453$

Overall, there is substantial evidence that COVID-19 has the potential to increase antiimmigrant attitudes among Leavers but not among Remainers. While we hypothesized a potential lessening of anti-immigrant among Remainers, the heterogeneity in the effects of COVID-19 on anti-immigrant attitudes between Leavers and Remainers is generally as we expected given the centrality of immigration attitudes in distinguishing these identity groups.

\section{Conclusion}

In the UK, the outbreak of COVID-19 took place against the backdrop of a period of considerable political volatility. In the five years before the pandemic the UK had witnessed the shock vote for Brexit, a protracted national debate about this result, the electoral rise of national populist parties and the broader fragmentation of the party system. The issue of immigration was central to this debate, with negative attitudes towards the free movement of labour from other EU member states, or a desire to reform immigration, being a driver of public support for Brexit, the national populist Brexit Party and Boris Johnson's Conservative Party. 
Media reports suggest the coronavirus may be increasing hate crimes and has the potential to inflame pre-existing anti-immigrant attitudes. At the same time, the national debate over COVID-19 has seen much media draw attention to the positive contribution that migrant workers make, particularly in the National Health Service (NHS). While it may be too early to investigate the full effects of COVID-19 on public opinion, our innovative survey experiment shows that in the context of Brexit negotiations, COVID-19 may indeed exacerbate anti-immigrant attitudes among Brexit Leavers while having little effect on Remainers. If this is so, the gap in immigration attitudes between the two identity groups may only widen further. Finally, while we focused on a particular identity made highly salient by the national political context, we expect that other political identities and their constituent attitudes, values and attributes might play a role in the heterogeneity of threat effects in other political contexts (e.g., partisan identities in the US). 


\section{References}

Amengay, A., and D. Stockemer. 2019. "The radical right in Western Europe: a meta-analysis of structural factors." Political Studies Review 17(1): 30-40.

Anderson, C.J., S.M. Mendes, Y.V. Tverdova, and H. Kim. 2004. “Endogenous Economic Voting: Evidence from the 1997 British Election." Electoral Studies 23(4): 683-708.

Brader, T., N.A. Valentino, E. Suhay. 2008. "What Triggers Public Opposition to Immigration? Anxiety, Group Cues, and Immigration Threat." American Journal of Political Science 52(4):959-978.

Ceobanu, A.M., and X. Escandell. 2010. “Comparative analyses of public attitudes toward immigrants and immigration using multinational survey data: A review of theories and research." Annual review of sociology 36: 309-328.

Clarke, H.D., Goodwin, M.J., Goodwin, M.J., and Whiteley, P. 2017. Brexit: Why Britain Voted to Leave the European Union. Cambridge University Press

Colantone, I., and P. Stanig. 2018. "Global competition and Brexit." American Political Science Review 112(2):201-218.

Curtice J. 2017. "Why Leave won the UK's EU referendum." J. Common Mkt. Stud.. 55:19.

Das, Enny, et al. "How terrorism news reports increase prejudice against outgroups: A terror management account." Journal of Experimental Social Psychology 45.3 (2009): 453-459.

De Rooij, E.A., M.J. Goodwin, and M. Pickup. 2015. "Threat, Prejudice and the Impact of the Riots in England." Social Science Research (51): 369-383.

Eatwell, R., and M.J. Goodwin. 2018. National populism: The revolt against liberal democracy. Penguin 
Eicher, V., \& Bangerter, A. 2015. "Social representations of infectious diseases." In G. Sammut, E. Andreouli \& G. Gaskell (Eds.), The Cambridge handbook of social representations (pp.385396). Cambridge, UK: Cambridge University Press.

Evans, G., and R. Andersen. 2006. "The Political Conditioning of Economic Perceptions.'” Journal of Politics 68(1):194-207.

Evans, G. and M. Pickup. 2010. “Reversing the Causal Arrow: The Political Conditioning of Economic Perceptions in the 2000-2004 US Presidential Election Cycle." Journal of Politics 72(4): 1236-51.

Ford R. 2018. "How have attitudes to immigration changed since Brexit?" Medium.

Goodwin, M.J., and O. Heath. 2016. "The 2016 referendum, Brexit and the left behind: An aggregate-level analysis of the result." The Political Quarterly 87(3):323-332.

Goodwin, M., and C. Milazzo. 2017. "Taking back control? Investigating the role of immigration in the 2016 vote for Brexit." The British Journal of Politics and International Relations 19(3):450-464.

Greenberg, J., Landau, M.J., Kosloff, S., Soenke, M., \& Solomon, S. 2016. How our means for feeling transcendent of death foster prejudice, stereotyping, and intergroup conflict: Terror management theory. In T. D. Nelson (Ed.), Handbook of prejudice, stereotyping, and discrimination, $2^{\text {nd }}$ ed. (p. 107-148). New York: Psychology Press.

Hainmueller, J., and D.J. Hopkins. 2014. "Public attitudes toward immigration." Annual Review of Political Science 17.

Harell, A., S. Soroka, and S. Iyengar. 2017. "Locus of control and anti-immigrant sentiment in Canada, the United States, and the United Kingdom." Political Psychology 38(2):245-260. 
Hobolt, S.B and M. Sorace. 2020. "A tale of two peoples: motivated reasoning in the aftermath of the Brexit vote." Political Science Research and Methods In Press.

Hobolt, S.B. 2016. "The Brexit vote: a divided nation, a divided continent." Journal of European Public Policy 23(9):1259-1277.

Hobolt, S., Leeper, T., \& Tilley, J. 2020. “Divided by the Vote: Affective Polarization in the Wake of the Brexit Referendum." British Journal of Political Science 1-18.

Joffe, H. 1999. Risk and 'the other' Cambridge, UK: Cambridge University Press.

Kaufmann, E. 2018. Whiteshift: Populism, immigration and the future of white majorities. Penguin.

Quillian, L. 1995. Prejudice as a response to perceived group threat: Population composition and anti-immigrant and racial prejudice in Europe. American sociological review, 60(4),586611.

Ramasubramanian, S. 2015. Using celebrity news stories to effectively reduce racial/ethnic prejudice. Journal of Social Issues, 71(1), 123-138.

Schwartz, C., Simon, M., Hudson, D., \& van-Heerde-Hudson, J. 2020. A Populist Paradox? How Brexit Softened Anti-Immigrant Attitudes. British Journal of Political Science, 1-21,

Sniderman, P. M., Hagendoorn, L., \& Prior, M. 2004. Predisposing factors and situational triggers: Exclusionary reactions to immigrant minorities. American political science review, $98(1): 35-49$

Stephan, W. G., Renfro, C. L., Esses, V. M., Stephan, C. W., \& Martin, T. 2005. The effects of feeling threatened on attitudes toward immigrants. International Journal of Intercultural Relations, 29(1), 1-19. 
Taber, C. and M. Lodge. 2006. "Motivated Scepticism in the Evaluation of Political Beliefs." American Journal of Political Science 50:755-769.

Valentino, N.A., T. Brader, and A.E. Jardina. 2013. "Immigration Opposition Among U.S. Whites: General Ethnocentrism or Media Priming of Attitudes About Latinos?" Political Psychology 34(2):149-166. 


\section{Online Supplementary Information A: Survey Questions}

\section{IMMIGRATION BLOCK}

How many new immigrants should the UK admit?

Many Fewer

Somewhat less

About the same as now

Somewhat more

Many more

There are too many people from other EU countries living in the UK.

Strongly disagree

Somewhat disagree

Slightly disagree

Slightly agree

Somewhat agree

Strongly agree

Migrants from other EU countries are the main cause of unemployment in the UK.

Strongly disagree

Somewhat disagree

Slightly disagree

Slightly agree

Somewhat agree

Strongly agree 
Immigrants to the UK can retain their cultural values without being any less British.

Strongly disagree (1)

Somewhat disagree (2)

Slightly disagree (3)

Slightly agree (8)

Somewhat agree (4)

Strongly agree (5)

To what extent do you think the UK should allow people from the poorer countries outside Europe to come and live here?

Allow none (1)

Allow a few (4)

Allow some (5)

Allow many (6)

\section{COVID-19 BLOCK $^{13}$}

How concerned are you about the threat posed to the United Kingdom by the coronavirus (COVID-19)?

Not at all concerned

Not very concerned

Somewhat concerned

Very concerned

Extremely concerned

Don't know

\footnotetext{
${ }^{13} 25 \%$ of respondents also received the question: Do you agree or disagree that the UK government should extend
} the Brexit transition period in response to the COVID-19 crisis? 
How concerned would you say you are right now about each of the following?

$\begin{array}{ccccc}\begin{array}{c}\text { Not at all } \\ \text { concerned }\end{array} & \begin{array}{c}\text { Slightly } \\ \text { concerned }\end{array} & \begin{array}{c}\text { Somewhat } \\ \text { concerned }\end{array} & \text { Very concerned } & \begin{array}{c}\text { Extremely } \\ \text { concerned }\end{array}\end{array}$

\section{Personally contracting COVID-19 \\ A friend or family member contracting COVID-19 \\ Someone in your local community contracting COVID-19}

Your ability to pay your bills

Your job security

The availability of food and supplies in your area

The ability of the NHS/HSC to provide adequate care in the event of illness or injury

The British economy

The global economy

The government response to the COVID-19 pandemic

Other (Please specify): 
Do you agree or disagree that the UK government is doing enough to protect people in the UK from the risk posed by the coronavirus (COVID-19)?

Strongly disagree

Somewhat disagree

Neutral

Somewhat agree

Strongly agree

Don't know

Do you believe that the present action being taken by the British government in response to COVID-19 is an overreaction, an under-reaction, or appropriate given the circumstances?

Significant overreaction

Slight overreaction

Appropriate given the circumstances

Slight under-reaction

Significant under-reaction

Don't know

Are you personally taking more precautions in your daily life to reduce the potential risk posed by the coronavirus (COVID-19)?

Not at all

Somewhat more precautions

Many more precautions

Don't know 
Are you personally taking additional precautions in your daily life in response to the potential risk posed by COVID-19?

No additional precautions whatsoever

A few additional precautions

Many additional precautions

What changes, if any, have you made to your normal routine in response to the COVID-19 pandemic? Please select all that apply.

Washing hands more often with soap and water

Cleaning and disinfecting frequently touched surfaces and objects more often

Using alcohol-based hand sanitisers more often

Not going into work or working from home more than usual

Avoiding all non-essential in-person contact outside your household

Staying in a separate room from others in your home

Using a separate bathroom from others in your home

Avoiding gatherings of more than 10 people

Avoiding gatherings of more than 50 people

Avoiding common greetings, such as handshakes

Avoiding crowded places

Keeping a distance of at least 2 arms lengths (approximately 2 metres) from others, as much as possible

Coughing or sneezing into a tissue or the bend of your arm instead of your hand

Avoiding touching your eyes, nose, or mouth with unwashed hands

Avoiding travel outside the UK

Avoiding travel within the UK

Shifting more of your shopping from physical stores to online

Avoiding people who are more likely to have come in contact with the coronavirus such as those who have recently travelled internationally

Avoiding public transport

Wearing a disposable mask

Wearing disposable gloves

Other (Please specify):

None of the above 
Do you know anyone personally who has been diagnosed with coronavirus or COVID-19?

No

Yes

How confident are you in the British government's ability to safeguard the health and well-being of the British people throughout the COVID-19 pandemic?

Not at all confident

Somewhat confident

Very confident

Extremely confident

Don't know 
Online Supplementary Information B: Balance Test

\begin{tabular}{|c|c|c|c|}
\hline & & Leave & Remain \\
\hline Gender & Female & $\begin{array}{l}-0.174 \\
(1.06)\end{array}$ & $\begin{array}{l}0.023 \\
(0.16)\end{array}$ \\
\hline Age & (5 year increments) & $\begin{array}{l}0.027 \\
(1.26)\end{array}$ & $\begin{array}{l}0.010 \\
(0.47)\end{array}$ \\
\hline \multirow[t]{20}{*}{ Education } & CSE grades 2-5 (Base) & & \\
\hline & City \& Guilds certificate & $\begin{array}{l}0.182 \\
(0.34)\end{array}$ & \\
\hline & City \& Guilds certificate - advanced & $\begin{array}{l}-0.625 \\
(1.92)\end{array}$ & $\begin{array}{l}0.921 \\
(1.51)\end{array}$ \\
\hline & City \& Guilds certificate - advanced & $\begin{array}{l}0.074 \\
(0.20)\end{array}$ & $\begin{array}{l}0.119 \\
(0.21)\end{array}$ \\
\hline & Clerical and commercial & $\begin{array}{l}-0.464 \\
(0.89)\end{array}$ & $\begin{array}{l}1.320 \\
(0.75)\end{array}$ \\
\hline & GCE A level or Higher Certificate & $\begin{array}{l}-0.215 \\
(0.86)\end{array}$ & $\begin{array}{l}0.271 \\
(0.76)\end{array}$ \\
\hline & No formal qualifications & $\begin{array}{l}-0.200 \\
(0.61)\end{array}$ & $\begin{array}{l}-0.108 \\
(0.18)\end{array}$ \\
\hline & Nursing qualification (e.g. SEN, SRN, SCM, RGN) & $\begin{array}{l}-0.675 \\
(1.15)\end{array}$ & $\begin{array}{l}0.651 \\
(0.64)\end{array}$ \\
\hline & ONC & $\begin{array}{l}-0.889 \\
(1.44)\end{array}$ & $\begin{array}{l}0.964 \\
(0.91)\end{array}$ \\
\hline & Other technical, professional or higher qualification & $\begin{array}{l}-0.332 \\
(1.38)\end{array}$ & $\begin{array}{l}0.538 \\
(1.57)\end{array}$ \\
\hline & Prefer not to say & $\begin{array}{l}-0.055 \\
(0.12)\end{array}$ & $\begin{array}{l}-0.170 \\
(0.24)\end{array}$ \\
\hline & Recognised trade apprenticeship completed & $\begin{array}{l}-0.256 \\
(0.63)\end{array}$ & $\begin{array}{l}1.319 \\
(1.90)\end{array}$ \\
\hline & Scottish Higher Certificate & $\begin{array}{l}0.068 \\
(0.10)\end{array}$ & $\begin{array}{l}2.023 \\
(2.41)^{*}\end{array}$ \\
\hline & Scottish Ordinary / Lower Certificate & $\begin{array}{l}0.662 \\
(0.52)\end{array}$ & \\
\hline & Teaching qualification (not degree) & $\begin{array}{l}0.403 \\
(0.67)\end{array}$ & $\begin{array}{l}0.071 \\
(0.11)\end{array}$ \\
\hline & University diploma & $\begin{array}{l}-0.622 \\
(1.87)\end{array}$ & $\begin{array}{l}0.291 \\
(0.76)\end{array}$ \\
\hline & $\begin{array}{l}\text { University or CNAA first degree (e.g. B.A., B.Sc., } \\
\text { B.Ed.) }\end{array}$ & -0.297 & 0.477 \\
\hline & & (1.28) & (1.54) \\
\hline & $\begin{array}{l}\text { University or CNAA higher degree (e.g. M.Sc., } \\
\text { Ph.D) }\end{array}$ & -0.336 & 0.549 \\
\hline & & (1.23) & (1.71) \\
\hline Religion & Anglican / Church of England (Base) & & \\
\hline
\end{tabular}


Baptist

Buddhist

Christian - No denomination

Hindu

Islam/Muslim

Jewish

Methodist

No religion

Other Christian denomination

Other Protestant denomination

Other non-Christian religion

Prefer not to say

Presbyterian / Church of Scotland

Roman Catholic

Sikh

United Reform Church (URC)

Occupation Administrative worker (Base)

Artist, designer, or lifestyle professional

Financial services or marketing professional

Have never worked

Manager or business owner

Manual labour and service

Natural resources or machine operative
$-0.633$

(0.93)

$-0.136$

(0.13)

0.065

(0.35)

$-1.768$

(0.95)

$-0.359$

(0.61)

0.559

(1.12)

$-0.009$

(0.06)

$-0.356$

(0.64)

1.601

(1.44)

0.431

(0.66)

0.177

(0.51)

$-0.317$

(0.70)

0.224

(1.05)

$-1.917$

(0.91)

$-0.762$

(0.60)
$-0.021$

(0.03)

0.566

(0.70)

$-0.035$

(0.12)

$-0.633$

(0.48)

0.316

(0.28)

1.310

(2.12)*

0.128

(0.23)

$-0.088$

(0.51)

0.665

(1.46)

0.177

(0.27)

$-0.365$

(0.55)

0.571

(1.36)

0.395

(0.77)

0.466

(1.78)

$\begin{array}{ll}0.707 & -0.027 \\ (1.36) & (0.06) \\ 0.468 & -0.089 \\ (1.41) & (0.25) \\ 0.878 & 0.805 \\ (0.69) & (0.90) \\ 0.184 & -0.315 \\ (0.82) & (1.20) \\ 0.483 & -0.068 \\ (1.29) & (0.16) \\ -1.236 & \\ (1.04) & \end{array}$


Prefer not to say

Professional

Public safety officer

Salesperson

Skilled labour

Skilled technician

Skilled technician in assistant capacity

Technical professions (science, engineering, medicine)

Transportation worker

Ethnicity African

Any other Asian background

Any other Mixed / Multiple ethnic background

Any other White background

Caribbean

English / Welsh / Scottish / Northern Irish / British

Indian

Irish

Other

Pakistani

Prefer not to say

White and Asian

White and Black Caribbean

Constant

$\begin{array}{ll}-0.509 & -0.175 \\ (1.46) & (0.44) \\ -0.030 & -0.329 \\ (0.13) & (1.36) \\ -1.064 & -0.568 \\ (2.04)^{*} & (0.88) \\ 0.230 & -0.431 \\ (0.62) & (0.97) \\ 0.356 & -0.247 \\ (1.09) & (0.47) \\ -0.499 & -0.219 \\ (1.30) & (0.47) \\ -1.724 & -2.041 \\ (1.57) & (1.59) \\ -0.077 & -0.030 \\ & \\ (0.25) & (0.10) \\ -0.457 & -0.376 \\ (1.24) & (0.73)\end{array}$

1.380

(0.68)

$-0.191 \quad-0.432$

$(0.11) \quad(0.44)$

$0.050 \quad-0.872$

(0.03) (1.10)

$-0.475$

$(-0.37)$

$-0.372 \quad-0.306$

$(0.25) \quad(0.41)$
1.036

$1.036 \quad 1.383$

$(0.48) \quad(0.79)$

$-1.352 \quad-0.882$

(0.84) (1.07)

$0.269 \quad-2.094$

$(0.15) \quad(1.57)$

$0.000 \quad-0.745$

$(-0.51)$

0.241

(0.14)

$-1.52$

(-1.37)

$-1.085$

$(-0.75)$

$0.553 \quad-0.039$ 


\begin{tabular}{|c|c|c|}
\hline & $(0.36)$ & $(0.04)$ \\
\hline $\mathrm{Chi}^{2}$ balance test $P$-value & 0.27 & 0.55 \\
\hline$N$ & 1,290 & 1,135 \\
\hline
\end{tabular}

For both Leavers and Remainers we cannot reject the hypothesis that the model containing gender, age, education, religion, occupation and ethnicity is no better at predicting assignment to treatment than the null model. $\mathrm{Chi}^{2}$ statistic $P$-values: 0.27 (Leavers); and 0.55 (Remainers). This indicates balance in assignment to treatment and control. 


\section{Online Supplementary Information C: Immigration Attitudes by Brexit Identity}

Figure A1. How many new immigrants should the UK admit?
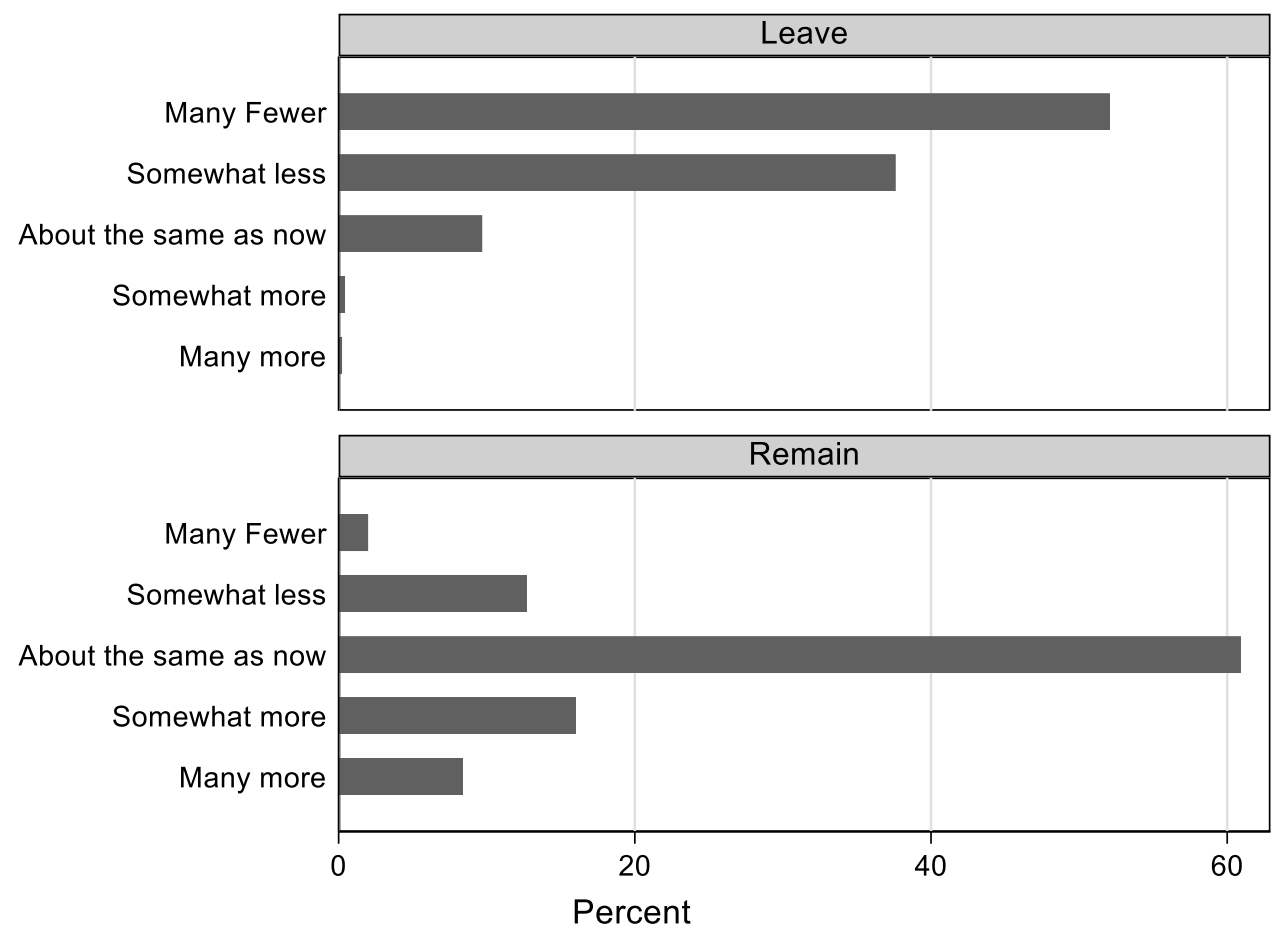

$\chi^{2}(4)=960.29 ; P$-value(one-sided) $<0.001 ; N=1602$ 
Figure A2. There are too many people from other EU countries living in the UK?
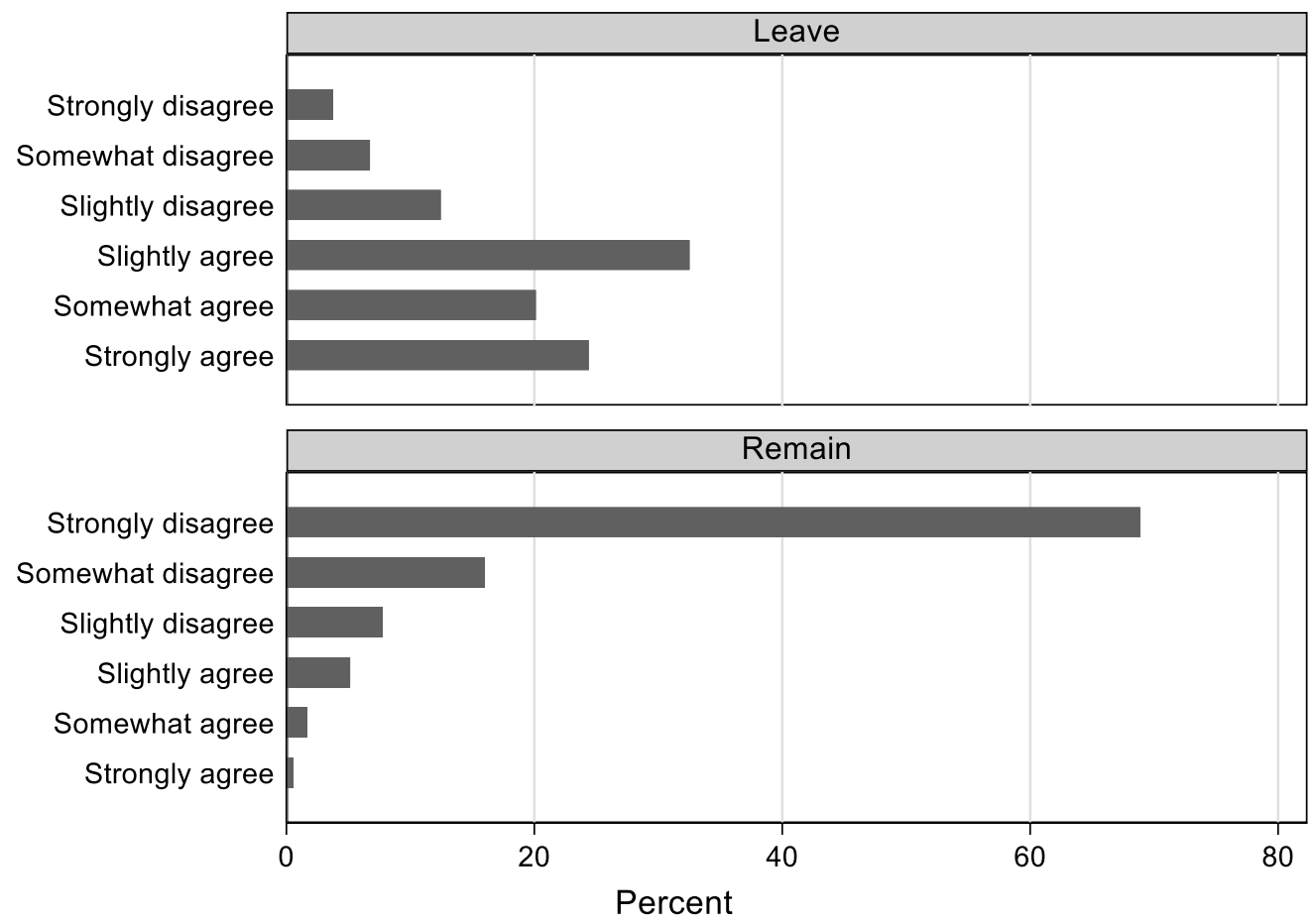

$\chi^{2}(5)=952.92 ; P$-value(one-sided) $<0.001 ; N=1601$ 
Figure A3. To what extent do you think the UK should allow people from the poorer countries outside Europe to come and live here?
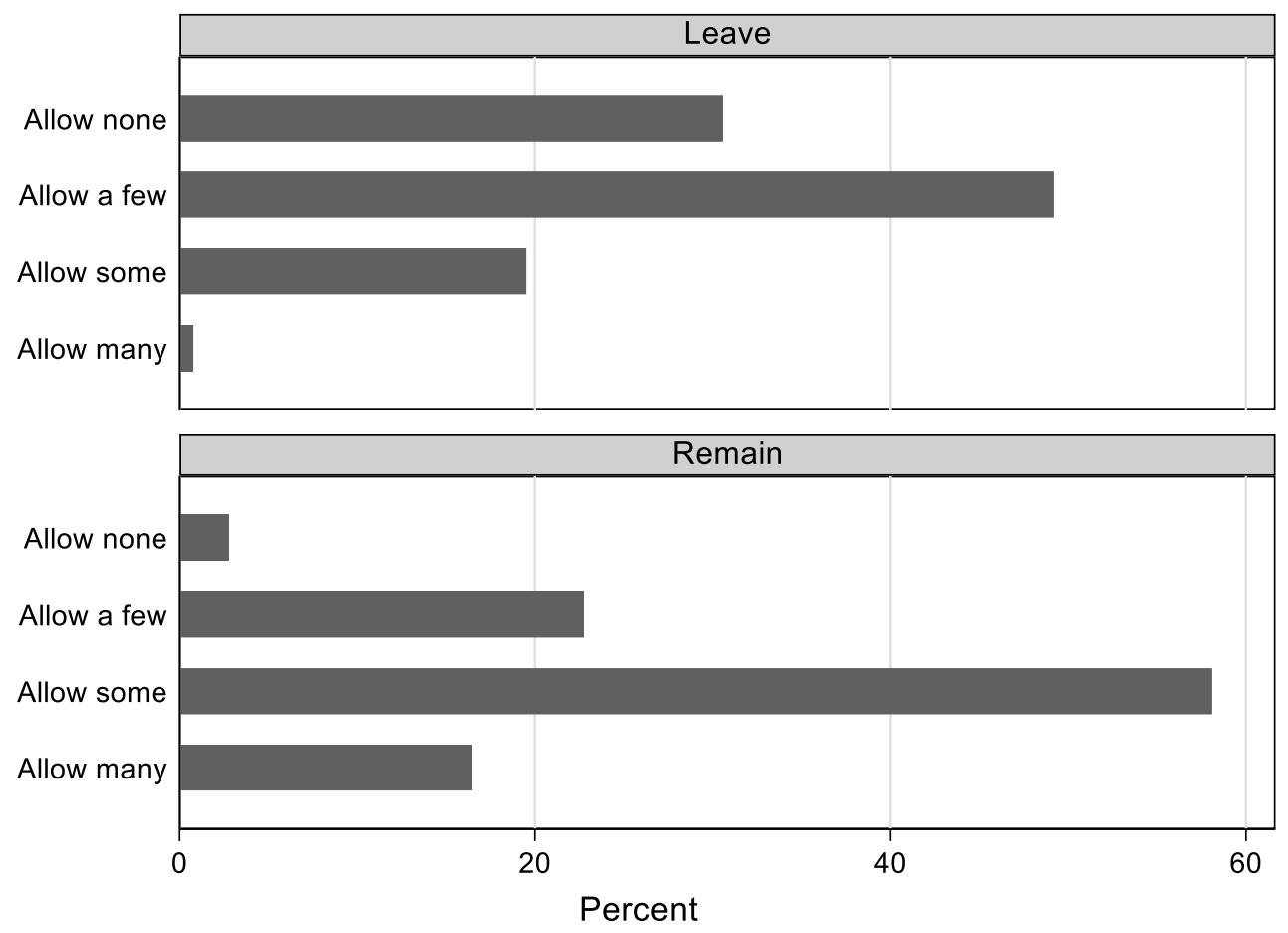

$\chi^{2}(3)=521.14 ; P$-value (one-sided) $<0.001 ; N=1545$ 
Figure A4. Migrants from other EU countries are the main cause of unemployment in the UK.
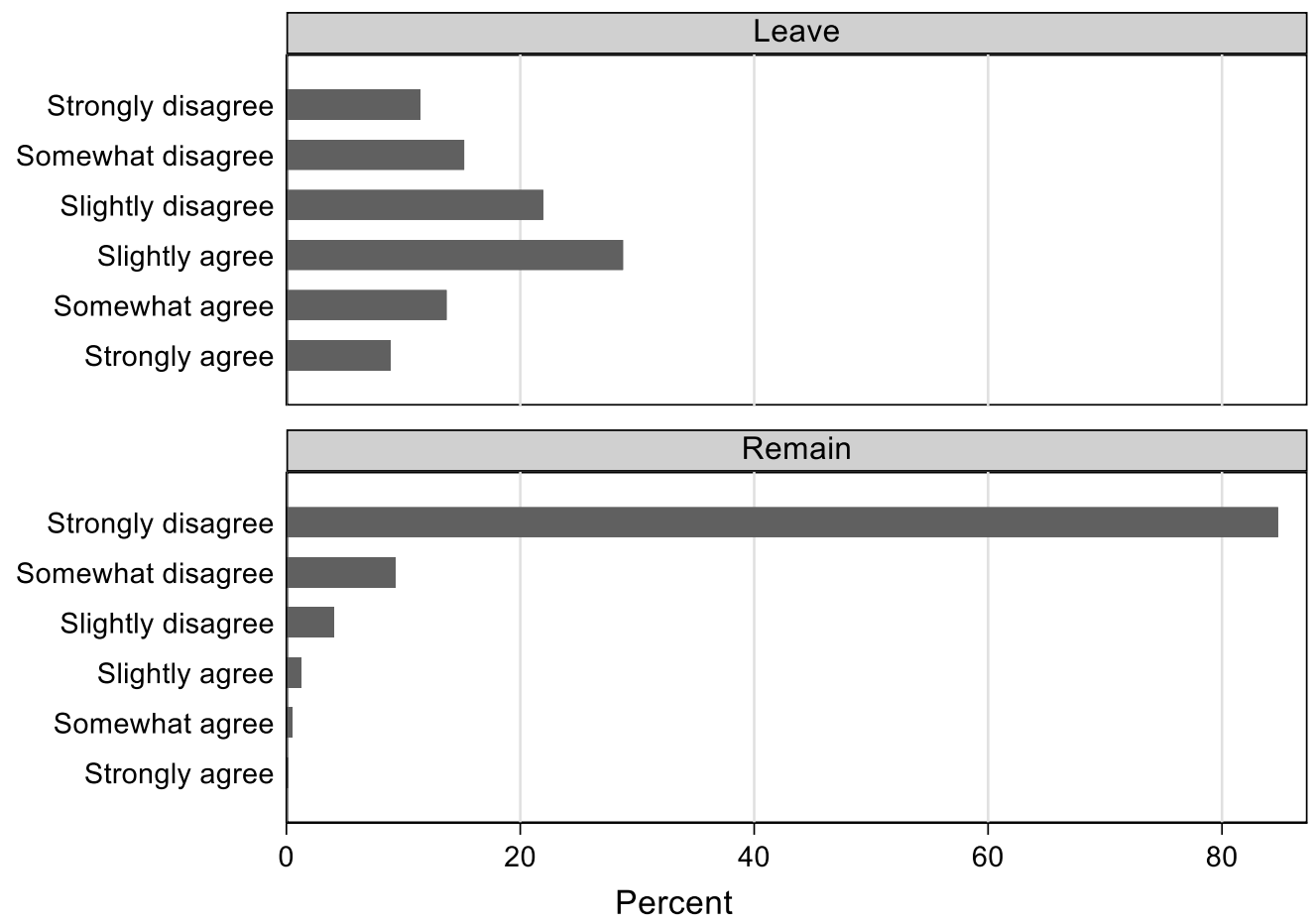

$\chi^{2}(4)=943.17 ; P$-value(one-sided) $<0.001 ; N=1597$ 
Figure A5. Immigrants to the UK can retain their cultural values without being any less British.
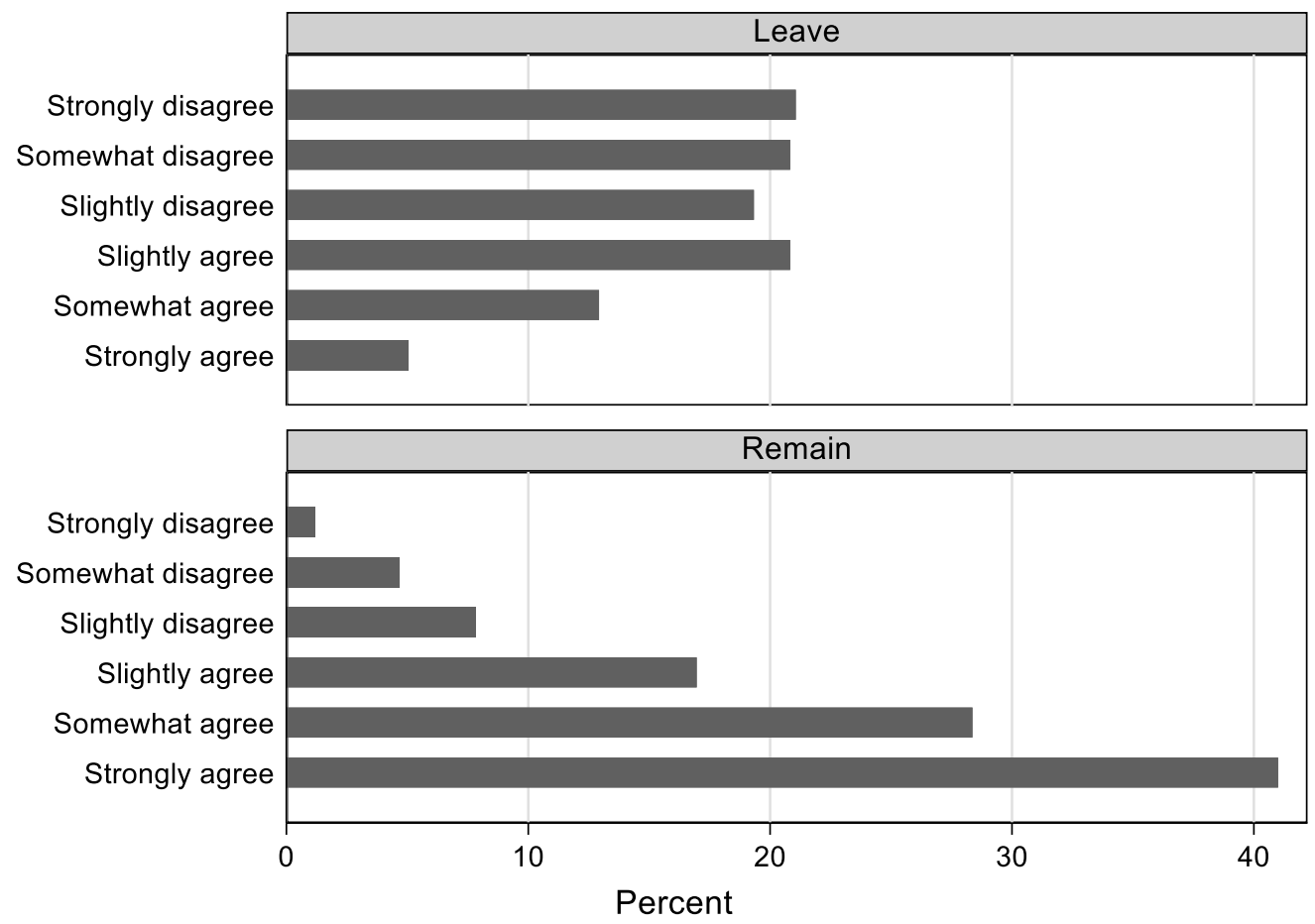

$\chi^{2}(4)=562.68 ; P$-value(one-sided) $<0.001 ; N=1602$ 